\title{
Study on Risk Society Governance in the Background of Globalization: Taking China as An Example Liang Dingcai ${ }^{1 *}$ Zhang Bo, Wang Jia ${ }^{2}$ \\ ${ }^{1,2}$ Yunnan University of Finance and Economics, Kunming, P.R.China 650000 \\ ( *dingcai2008@126.com )
}

\begin{abstract}
With the rapid development of human society, risks are emerging in an endless stream. the uncertainties of social development are existent at anymoment, and the huge risk happened stochastically. This paper is based on the background of globalization, and to analyze the characteristics and reasons of the risk society,and gives some basic strategies. Facing the society risks under the background of globalization, China will mobilize all social forces and establish the fair and reasonable interest distribution and coordination mechanism.
\end{abstract}

Keywords: risk society; public management; governance; globalization.

\section{Introduction}

Since Chinese reform and opening up, modern life has undergone enomous changes, especiallyunderthe impact of globalization, our world has become a "globalvillage",all countries began to frequent political, economic, trade, cultural activities.However, the uncertainties of social development are existent at anymoment, and the huge risk happens stochastically. In the twenty-first Century, there have been many disaster in the world, Such as global warming, 9.11 events, SARS virus, financial crisis, terrorism, etc. These global events remind us: the impact of globalization, revolution in science and technology, theknowledge economy, great changes have taken place in the world, we have entered a high risk society.

Now, we come to have a look Chinese social reality:Water pollution, air pollution, solid waste pollution, food safety incidents, nuclear pollution, terrorist attacks, the credit crisis, "SARS" virus, avian influenza, traditional cultural loss etc.Visible, China has also entered the risk society. the risk no longer is related to human health and safety problems, butthe relationship between human panorama and wellbeing. Risk has become a majer feature andperformance of modern society, its complexity, instability and disruptive enough to let us hard to manage.

For Chinese society, we are marching on the road of modernization development, and must bear the social risk of losses. So, faced with the risk of the more and more complicated and difficult to control, China how to seek development and breakthrough, this is a problem needs to be solved urgently.

\section{2. "Risk" and "risk society"}

Understanding of the "risk" is the basis and premise of "risk society". "Risk theory" is the basic category of the theory of "risk society". At present, the academic circles have not a unified view of"risk society".

In the modern Chinese Dictionary, "risk" is interpreted as "the possibility of danger". In English, the meaning of"risk" isthe expressionofa "disaster", it is derived from the French "risque", meaning to sail on the cliffs. And the French "risque" is derived from the Italian "risicare", it enhance the positive aspects of adventure of course, the risk has a negative sidealso has its positive side, in this paper, we study the negative risk.

Ulrich Beck, Wouter Achterberg, Anthony Giddens, Niklas Luhmann already have a systematic study 
of "risk" and "risk society" theory, and have created the theory about the risk society. Ulrich Beck in the book "risk society", firstly proposed the "risk", "risk society" and "risk society theory". He thinks, the risk is not equal to the damage, it has both positive and negative. In addition, he pointed out, the risk of modern society is different from theancient risks, risks of modern society is the result of modernization and globalization, modern risk is uncertainty and complexity. Like Beck, Wouter Achterberg believes that the risk is the result of lobalization and modernization. Anthony Giddens thinks, the risk is good or bad whether we like it or not, there are some risks that we must face, such as ecological catastrophe, nuclear war. At the same time, he believes that we are living in a hightech society, we now haveno way to anticipate and grasp the possible future. Niklas Luhmanndraws the conclusionthrough the analysis of the risk theory of Beck: many fields in modern society hasvariousrisk, the risk is a common phenomenon in society, the reasons for its formation is artificial.

Visible, theworld has entered into a high risk society, namely "risk society".The risk are bothadvantages and disadvantages, risk is the direct result of the success of modernization.Along with the economic growth and social progress, social disaster and social problems emerge in an endless stream, we

more and more can't control and solve various risk.

\section{Feature of "Risk Society"}

Globalization appeared as the cross-border movement of goods, capital, Human Resources. As we all know, Globalization is a new worldwide phenomenon since the 1980s, it is a basic feature on today. Although all of the age exist society risk, Risk under the background of economic globalization is more dangerous and challenging. Mainly in the following areas:

\subsection{The risks of globalization and large-scale}

The risk is under the globalization risk and crisis, it will threat the common interests of people when the risk expand and spread on global scale, which is different of risk of Regional or local In the past.

\subsection{The risk of complications and uncertainties}

Risk of harm caused by the context of globalization has far exceeded the traditional sense of threat as the continuous improvement of productivity. The increasing complexity of the relations of production trends appeared, new problems and new threats emerging. With the outbreak of the ecological crisis, the energy crisis, food security crisis, nuclear crisis, the financial crisis and the spread of the global crisis,the risk is turning in today's society, from natural risk to human risk, from individual risk, and regional risk to global risks, from material interests risk to Cultural risk, moral hazard and the theoretical risk. Trend is becoming complexity, uncertainty is increasing.

\subsection{The high Destructive ofrisk}

Risk under the globalization is more destructive than ever. Giddens put risk into External risk and created risk. He said: External risk is the risk from the outside caused by traditional or natural invariance and immobility. Created risk is the impact of knowledge about the world we are constantly developing arising and we do not have much historical experience. Many risks are the high technologyproducts, which are high destructive, even devastating because of we Lack of experience and high-tech power. 


\subsection{The Class nature of risk}

Classes and strata inequality caused resource inequality, which led to unequal treatment risk. As we all know, resources of our society is mainly concentrated in developed countries or in the hands of the upper class society, the status of the risk society mainly in the conflicts of power and ruled owners, social upper class and lower class. It is the existence of this state of affairs, Baker said in "risk society": a place where people die of hunger, andin another place, gluttony become an important issue in food consumption. When risks occur, different economic status of people will be varying degrees of damage.

\section{The Reasons for the formation of risk society}

Risk society is mainly due to globalization, social change, unequal distribution of wealth, the system is imperfect, large-scale use of technology to bring the environment and climate change, as well as a variety of man-made and natural disasters brought about changes in artificial.

4.1. The root cause is taking economic construction as the center development model

With the development of industrialization and modernizatio, the human thought themselves were the only ones in the universe, and can control nature.However, excessive practice of human being the nature of revenge, makes social contradictions emerge.

\subsection{The main reason is uneven distribution of benefits}

China has implemented the unbalanced development strategy since 1978. Implementation of this strategy has yielded significant results, but also had a negative effect, the main manifestations as follows: the state, society, human and nature are not a harmonious and balanced development, but an one-sided, unbalanced development. simple pursuit of GDP growth On the economic front, social stratification and interests split level intensified spiritual emergence Honesty, moral decline, plundered natural resource consumption between promoting economic growth, population, resources and environment have become increasingly prominent. The imbalance development strategy exacerbated the contradictions and conflicts between different social subjects, resulting in many serious social problems.

\subsection{Social transformation is breeding ground}

At present, the economic system of China is turning from the planned economy to market economy, China is moving from authoritarian political system to more equitable justice, and democracy political system. In the historical period of the change, the traditional distribution of benefits and coordination mechanism is broken, and the new fair and equitable distribution of benefits and coordination mechanisms are not yet fully established. Rapid social transformation and slow distribution and coordination mechanism between the interests of the process leading to the formation of contradictions emerged in China, many social problems have appeared, such as: increasing wealth gap, corruption a serious problem, lack of credibility, market disorder, etc., which is a serious challenge for building a socialist harmonious society.

\subsection{The incentive is the impact of globalization}

Globalization itself leads to global risks. Globalization is Economic Globalization,it is unfolding in the world division of labor and exchange activities worldwide. With the exchange activity expanded in the world, world history gradually formed, after that, each region increasingly closed. 
Accordingly, the risk became global risks, it is not just only a threat to one country or region, but the threat to the survival and developmentof the entire human race.

\section{The basic strategies}

When facing the sudden risks, we must actively implement the strategy self-protection, and only in this way, can we stand our ground in the changing risks.

\subsection{Establish the right development view}

For today's china, it is urgent to establish scientific development view and treat harmony society as an ideality. During the period of developing, we must get the balance of development among our country, society, human beings and nature and it is unadvisable to focus on one or only several aspects and ignoring others. And for the certain level, it is also unadvisable to take into consideration about one or several parts and overlooking the others.

\subsection{Establish fair and reasonable benefit distribution mechanism}

Social equality, political justice and political democracy should be the political developing value orientation of today's China, and the fair and reasonable benefit distribution mechanism should be one of the most important targets of the present stage. We must hold the opportunity to implement the reform of political structure and promote the developing of the democratic politics In different levels and from different points. Under the methods of institutional innovation, Political and cultural change, political ruling and optimizing political management ways, we must hold the opportunity of stabilization of politics and society and try out best to make our society move towards the direction of fairness, justice and democracy.

\subsection{Establish the socialized service system of government, market and society}

At present, our country's social distribution structure is just like a pyramid, and the resources and fortune flow from top to bottom and the risks in the opposite way. So, the result would be the state of fortune gathering in the top and risks in the bottom. As the diversity and complication of the risks in the rural community, to improve capability in shielding against risks of Individual and family in rural community, Professor Qian Ning suggest establishing a socialized service system of government, market and society. In the author's view, it is proper and advisable to provide protection and multi-layered service system for shielding against risks for families and community.

\subsection{Strengthen international security cooperation}

Economic globalization makes the human beings has begun to enter the world risk society. Society risk is obviously international, global and relevant in the era of globalization. In the process of attending economic globalization, China should improve the ability of obtaining profits; enhance independent innovation of science, technology and brand; and prevent western countries from transferring energy-guzzling and highpolluting industries to China. At the same time, China should cope with and prevent risks and challenges caused by economic globalization by widely international security cooperation, and do our duty for international security cooperation. This not only can prevent the global spread of society risks, but also resolve the security challenges in the economic globalization. In this way, our country can be 
threatened by the spread of international risks as little as possible and defend the national interests.

\section{Conclusions}

In a word, risky society has come. Facing the society risks under the background of globalization, our government can overcome the risks by mobilizing all social forces and establishing the fair and reasonable interest distribution and coordination mechanism.

\section{Acknowledgement}

This research was financially supported by the PublicAdministration, Yunnan University of Finance and Economics of China.Here, thanks to the support from the College.

\section{References}

[1]Anthony Giddens, the consequence of modernity [M],Tian, Yilin press, 2000,29-44

[2] Anthony Giddens, the runaway word [M], translated by Zhou Hongyun, Jiangxi people's publishing house,2001,20-23

[3] Germany] Beck. World risk society [M]. Wu Yingzi, Sun Shumin, trans.Nanjing: Nanjing University press, 2004.182

[4]Deborah Lup ton ed. 1999. Risk and Sociocultural Theory: New Di2rections and Perspectives. Cambridge: Cambridge University Press 1

[5] Modern Chinese dictionary [M]. Beijing: the Commercial Press, 2005

[6]N.Luhmann. 1993. Risk: A Sociological Theory. Berlin: de2Gruyter.

[7] Yang Xuedong. Global Risk Society for composite treatment

of[EB/OL],http://www.cass.net.cn/webnew/file/ , 2005-01-13.

[8] Wouter Achterberg .Democracy, justice and the risk society: the morphology and the significance of Ecological Democracy [M].2003,3.
[9]Zhou Zhanchao. Quote of Risk Society Theories of Contemporary Western[J]. Marxism \& Reality. 2003(3):53-59.

[10] Zhuang Yougang. A review of the theory of risk society [A]. Beijing:dynamics of philosophy, 2005 (9) 